\title{
LIVELIHOODMASYARAKAT KAMPUNG PELANGI, GUNUNG BRINTIK, KOTA SEMARANG MELALUI PENDEKATAN SUSTAINABLE URBAN LIVELIHOOD (SUL)
}

\author{
Livelihood Kampung Pelangi, Gunung Brintik, Semarang City \\ Through Sustainable Urban Livelihood (Sul) Approach
}

Tia Adelia Suryani ${ }^{1}$, Haryo Winarso $^{1}$

Diterima: 1 September 2018

Disetujui: 26 Juni 2019

\begin{abstract}
Abstrak: Pesatnya pertumbuhan penduduk Kota Semarang dan terbatasnya lahan permukiman mengakibatkan munculnya permukiman kumuh ilegal. Salah satu upaya pemerintah untuk merevitalisasi kawasan kumuh dengan mewarnai wilayah desa Gunung Brintik yang kemudian dikenal sebagai Kampung Pelangi. Beberapa program revitalisasi di negara lain belum berhasil meningkatkan livelihood penduduknya. Tujuan penelitian ini adalah untuk menguji keberhasilan pemerintah dalam meningkatkan livelihood Kampung Pelangi di Kota Semarang, melalui pendekatan Sustainable Urban Livelihood (SUL) dengan metode deskriptif kuantitatif dan teknik analisis skoring. Penelitian dilakukan pada dua waktu yang berbeda; sebelum pelaksanaan program Pemerintah Kota Semarang (tahun 2016) dan setelah implementasi (tahun 2018). Sebagai kontrol, Kampung Pandean dipilih karena memiliki kondisi serupa tetapi tidak mendapatkan program dari pemerintah. Hasil penelitian menunjukkan bahwa ada perubahan dalam livelihood penduduk di Kampung Pelangi meliputi kualitas sumber daya manusia, modal alam, modal sosial, dan modal fisik, sedangkan kondisi Kampung Pandean tidak menunjukkan perubahan selama 2016-2018. Perubahan ini bukan karena pewarnaan tetapi karena perbaikan kondisi fisik.
\end{abstract}

\section{Kata kunci: permukiman kumuh, kampung, revitalisasi, livelihood perkotaan.}

\begin{abstract}
The rapid growth of the population of Semarang City and the limited land for settlements resulted in the emergence of illegal slums. One of the government's efforts to revitalize the slum area by coloring Gunung Brintik village area which became known as Kampung Pelangi. Some slum revitalization programs in other countries have not succeeded in increasing residents' livelihood. The purpose of this study was to examine the success of the government in improving the livelihood of Kampung Pelangi in Semarang City, through the Sustainable Urban Livelihood (SUL) approach with quantitative descriptive methods and scoring analysis techniques. The study was conducted at two different times; before the implementation of the Semarang City Government program (in 2016) and after the implementation (in 2018). As a control, Kampung Pandean was chosen because it had similar conditions but did not get any program from the government. The results showed that there was a change in the livelihood of the population in Kampung Pelangi include the quality of human capital, natural capital, social capital, and physical capital, while the condition of Kampung Pandean does not show any changes during 2016-2018. This change is not due to coloring but due to improvements in physical conditions.
\end{abstract}

Keywords: kampung, revitalization, slums, urban livelihood

\footnotetext{
${ }^{1}$ Perencanaan Wilayah dan Kota, Institut Teknologi Nasional (ITENAS).

${ }^{1}$ Perencanaan Wilayah dan Kota (PWK), Sekolah Arsitektur, Perencanaan dan Pengembangan Kebijakan (SAPPK), ITB.
} 


\section{PENDAHULUAN}

Urbanisasi yang pesat perlu didukung dengan struktur politik dan ekonomi yang lebih modern guna meningkatkan produktifitas. Namun, beberapa kota tumbuh dua kali lebih cepat dibanding populasi nasional sehingga seringkali menyebabkan pendapatan pribadi dan sumber daya nasional untuk pelayananan publik dan pembangunan perkotaan menjadi tidak memadai (Turner, 1968). Keterbatasan lahan permukiman dan/atau harga rumah yang semakin tinggi mengakibatkan munculnya fenomena kawasan permukiman kumuh, sebagai jawaban atas kebutuhan permukiman yang dapat dijangkau oleh masyarakat berpenghasilan rendah. Permukiman adalah bagian dari lingkungan hunian yang terdiri atas lebih dari satu satuan perumahan yang mempunyai prasarana, sarana, utilitas umum, serta mempunyai penunjang kegiatan fungsi lain di kawasan perkotaan atau kawasan perdesaan (Undang Undang No.1, 2011).

Permukiman Kumuh adalah permukiman yang tidak layak huni karena ketidakteraturan bangunan, tingkat kepadatan bangunan yang tinggi, dan kualitas bangunan serta sarana dan prasarana yang tidak memenuhi syarat (Menteri Pekerjaan Umum dan Perumahan Rakyat, 2016). Kawasan kumuh hampir tidak mungkin untuk dihilangkan seluruhnya, dibutuhkan proses yang berkelanjutan dalam menyelesaikan masalah kumuh di perkotaan (Balchin, 1979). Permukiman kumuh ini dapat berupa slum area yaitu yaitu permukiman dengan kondisi lingkungan yang tidak layak huni namun bersifat legal yang secara hukum diakui kepemilikannya, atau squatter area yaitu permukiman kumuh yang dibangun di suatu kawasan/daerah permukiman/tempat-tempat terlarang dan bersifat ilegal atau liar. Permukiman informal memiliki ciri umum memiliki livelihood yang rendah, fasilitas umum yang buruk, serta tingkat kemiskinan yang tinggi (Calderon, 2012).

Kampung mewakili 'dualistik' model struktur sosio ekonomi sebuah kota di negara berkembang secara tradisional maupun modern, formal maupun informal, dan aktivitas legal maupun ilegal (McGee, 1996). Kampung pada awalnya merupakan konotasi negatif dari sebuah permukiman. Identik dengan ketidakteraturan dan kondisinya yang kumuh. Akan tetapi semenjak banyak bermunculan program-program perbaikan kampung (Kampung Improvement Program). Kampung merupakan bagian integral dari suatu kota (Nas, 1986). Kampung adalah kelompok perumahan yang merupakan bagian kota, mempunyai kepadatan penduduk yang tinggi, kurang sarana dan prasarana, tidak ada luasan tertentu, jadi dapat lebih besar dari satu kelurahan, mengandung arti perumahan yang dibangun secara tidak formal (mengikuti ketentuan-ketentuan kota yang bersangkutan) kampung kota dihuni sangat padat dan cenderung semakin padat, sehingga kesehatan merupakan masalah utama (Ikatan Ahli Perencanaan Direktorat Jenderal Cipta Karya, 1998). Kedudukan dan pengertian kampung semakin positif. Saat ini telah banyak program slum upgrading yang dilakukan oleh berbagai negara. Transformasi kampung dalam rangka slum upgrading dapat berdampak pada livelihood penduduk.

Beberapa negara berhasil menerapkan program-program perbaikan kampung (Kampung Improvement Program) dengan tepat dan membawa dampak positif terhadap kesejahteraan penduduknya, diantaranya adalah Thailand. Pada tahun 2003, terdapat 10 (sepuluh) program revitalisasi kawasan kumuh di Bangkok, Thailand yaitu Baan Mangkong. Program ini bertujuan untuk menyediakan rumah dengan status kepemilikan yang terjamin. Rumah permanen dan yang telah diperbaiki kualitasnya dapat membantu masyarakat berintegrasi dengan lingkungan perkotaannya (Archer, 2012). Surabaya merupakan salah satu Kota yang memiliki sejarah panjang dan telah berhasil mengimplementasikan Kampung Improvement Program. Fokus perbaikan berkembang dalam 4 (empat) tahap, dimulai dari aspek fisik, sosial ekonomi, secara komprehensif (tridaya), dan pengembangan sumber daya manusia (Dianingrum, et al, 2017). Permukiman 
kumuh Mesir diakibatkan oleh kemrosotan persediaan perumahan sewa yang tersedia dan adanya pergeseran ekonomi melalui industrialisasi. Akibatnya, masyarakat kelas menengah dan MBR terdorong melakukan urbanisasi secara informal ke lahan pertanian di pinggiran Kota. Penekanan upaya perbaikan terletak pada kebijakan pemberian pinjaman dan integrasi kebijakan perumahan yang berfokus pada legalisasi kepemilikan, perbaikan infrastruktur, dan fasilitasi kredit (Khalifa, 2015). Pemerintah Kota Durban, Afrika Selatan berperan sebagai 'pengembang' yang mengambil alih seluruh aktivitas perencanaan di dalamnya. Proyek perbaikan lingkungan permukiman kumuh dimulai pada 2005 dan dianggap sukses karena dapat memenuhi kebutuhan dasar perumahan, meningkatkan kekuatan politik, serta dapat meningkatkan hak kepemilikan dan kesejahteraan penghuni. Keberhasilan ini bergantung pada kontinuitas informal, khususnya kekuatan konsolidasi dari komite pengembangan masyarakat lokal yang konsisten (Patel, 2013).

Tidak semua program berhasil sesuai yang diharapkan. Beberapa negara gagal menerapkan program tersebut karena beberapa alasan, sehingga program perbaikan kampung tidak dapat meningkatkan kesejahteraan penduduknya, diantaranya Art Village di Beijing, Cina (Liu, et al, 2013) dan Gecekondu di Turki (Erman, 2016). Banyaknya program serupa yang sudah diterapkan berbagai negara menunjukkan bahwa tidak mudah mengimplementasikan program perbaikan kampung yang dapat meningkatkan kualitas livelihood penghuniya. Perlunya evaluasi pada tahap awal yang diteruskan secara berkala untuk mengetahui apakah program tersebut berjalan dengan baik dan dapat diteruskan. Apabila masih terdapat kekurangan maka perlu adanya perbaikan agar program berjalan dengan optimal. Livelihood merupakan istilah yang diadopsi dari Bahasa Inggris yang berarti pembangunan yang menggambarkan kemampuan, kepemilikan sumber daya dan kegiatan yang dibutuhkan seseorang/masyarakat untuk menjalani kehidupannya (Saragih, S., 2007). Livelihood didefinisikan sebagai cadangan yang memadai bagi arus makanan serta uang tunai untuk memenuhi kebutuhan dasar. Secara sederhana diartikan sebagai cara untuk memperoleh nafkah. Livelihood terdiri dari kemampuan, aset dan kegiatan yang diperlukan untuk sarana hidup (Chambers \& Conway, 1991).

Pada awalnya, livelihood lebih banyak diterapkan pada kawasan pedesaan. Salah satunya adalah penelitian mengenai karakteristik dan faktor pendorong transisi livelihood pedesaan wilayah pesisir timur Cina. Proporsi rumah tangga konvensional menurun dan proporsi rumah tangga yang berorientasi pada pekerjaan di luar pertanian dan rumah tangga di luar pertanian meningkat (Z. Liu \& Liu, 2016). Penelitian mengenai livelihood pedesaan juga dilakukan dengan meneliti kepekaan strategi mata pencaharian terhadap modal mata pencaharian di pegunungan melalui analisis empiris berdasarkan berbagai permukiman di pinggiran Sungai Minjiang, Cina. Modal alam dan manusia menunjukkan korelasi positif terhadap strategi mata pencaharian pertanian, meskipun efeknya bervariasi dengan empat jenis permukiman. Modal finansial dan modal sosial berperan sebagai katalis untuk menggerakkan kegiatan non-pertanian. Tidak ada ukuran yang cocok untuk semua solusi terhadap isu strategi mata pencaharian, dan hanya mata pencaharian yang dapat membantu dalam jangka panjang jika dilengkapi dengan kebijakan relatif yang meningkatkan kapasitas modal serta meningkatkan akses ke ibukota (Fang, Fan, Shen, \& Song, 2014). Livelihood masyarakat pedesaan yang terkait dengan demografi rumah tangga pedesaan, mata pencaharian dan lingkungan menunjukkan bahwa melalui keterkaitan yang dimediasi oleh banyak faktor, terdapat bukti kuat bahwa ketergantungan pada sumber daya alam meningkat ketika rumah tangga kehilangan modal manusia dan sosial. (de Sherbinin et al., 2008).

Masyarakat perkotaan menghadapi kendala dalam memperoleh livelihood yang baik. Livelihood masyarakat miskin perkotaan ditentukan sebagian besar oleh peluang dan kendala yang terdapat di lingkungan tempat tinggal mereka (Ashley \& Carney, 1999). Livelihood mengandung arti sebagai aset atau modal yang antara lain meliputi Human 
Capital, Social Capital, Physical Capital, Financial Capital, Natural Capital (Balee \& Jruek, 2006; FAO, 2008; Farrington, Ramasut, \& Walker, 2002). Oleh karena itu muncul konsep livelihood perkotaan yang disebut Sustainable Urban Livelihood (SUL) dalam rangka memahami sifat penghidupan perkotaan dalam konteks perkotaan. Konsep ini didasarkan pada aspek-aspek kunci berupa konteks sosial, konteks ekonomi, dan hubungan lingkungan dan kesehatan dan perkotaan (Meikle, Ramasut, \& Walker, 2001).

Pemerintah Kota Semarang berinisiatif untuk melakukan upaya yang mirip dengan tujuan perbaikan kualitas kampung/permukiman kumuh. Peningkatan kualitas terhadap perumahan kumuh dan permukiman kumuh adalah upaya untuk meningkatkan kualitas bangunan, serta prasarana, sarana dan utilitas umum (Menteri Pekerjaan Umum dan Perumahan Rakyat, 2016). Salah satu upaya Pemerintah Kota Semarang untuk perbaikan kualitas kampung/permukiman kumuh ini bermula dari rencana perbaikan Pasar Bunga Kalisari dan perbaikan wajah sungai. Pemerintah menganggap permukiman kumuh yang ada di dekatnya harus diperbaiki juga kualitasnya. Strategi yang dipilih adalah dengan melakukan pengecatan Kampung Gunung Brintik yang sekarang lebih dikenal dengan Kampung Pelangi.

Belum diketahuinya kualitas livelihood masyarakat Kampung Pelangi setelah dilakukan upaya awal perbaikan kampung menjadi menarik untuk diteliti. Tujuan penelitian ini untuk mengkaji perubahan kualitas livelihood masyarakat Kampung Pelangi melalui pendekatan Sustainable Urban Livelihood (SUL) dan menjelaskan perbedaan kualitas livelihood masyarakat Kampung Pelangi dengan Kampung Pandean sebagai kampung kontrol.

\section{METODE}

\section{Lokasi penelitian}

Penelitian ini dilakukan di dua lokasi yang berbeda yaitu Kampung Pelangi dan Kampung Pandean. Kampung Pelangi terletak di tengah Kota Semarang tepatnya di Jalan Dr.Soetomo, Kelurahan Randusari, Kecamatan Semarang Selatan, Kota Semarang. Kampung Pelangi meliputi 2 RW, yaitu RW 3 dan RW 4 dengan 19 RT. Lokasinya berada di belakang deretan Pasar Bunga Kalisari Kota Semarang. Kampung Pandean terletak di tengah Kota Semarang tepatnya di Jalan Pandean, Kelurahan Peterongan, Kecamatan Semarang Selatan, Kota Semarang. Kampung Pandean merupakan salah satu kawasan yang masuk dalam kawasan kumuh Kota Semarang (Pemerintah Kota Semarang, 2014).

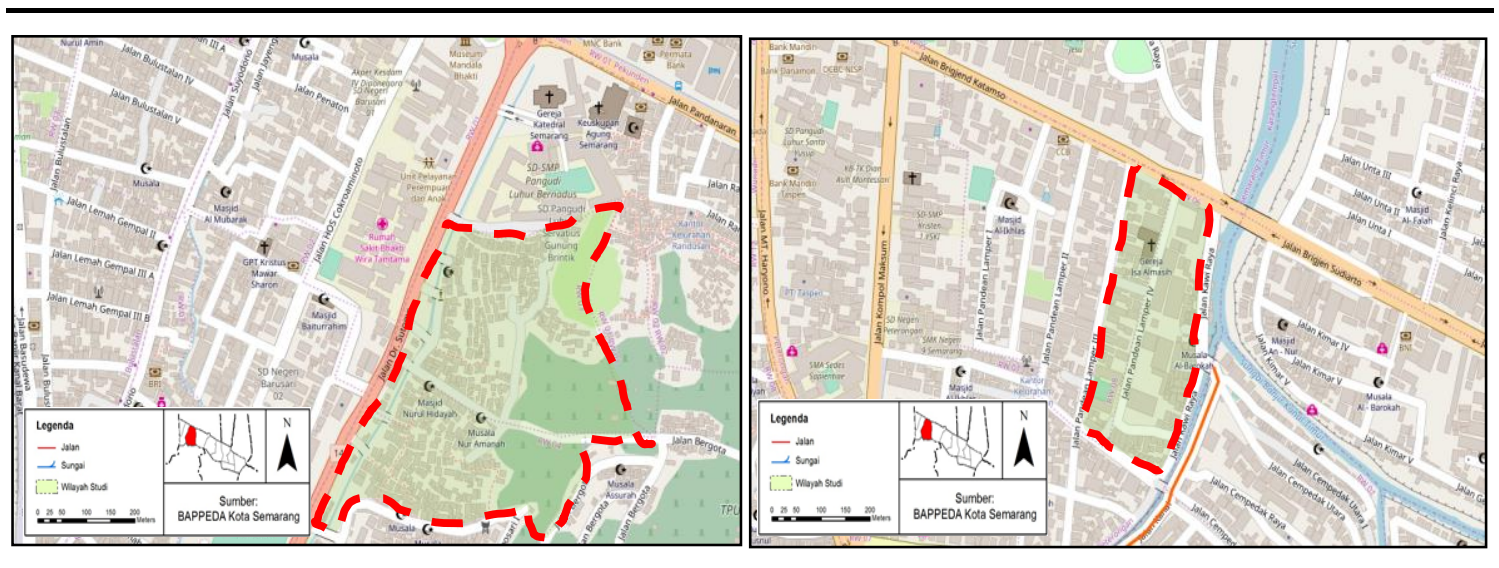

Gambar 1. Lokasi Kampung Pelangi dan Kampung Pandean. 
Penelitian ini merupakan penelitian yang bertujuan untuk mengkaji livelihood masyarakat Kampung Pelangi, Gunung Brintik, Kota Semarang melalui pendekatan Sustainable Urban Livelihood (SUL). Dalam mencapai tujuan tersebut digunakan metode deskriptif komparatif. Adapun teknik analisis yang digunakan adalah analisis statistik deskriptif dan skoring, melalui pendekatan Sustainable Urban Livelihood (SUL). Analisis yang dilakukan meliputi:

- Analisis aset livelihood di Kampung Pelangi meliputi modal sumberdaya manusia, sumberdaya alam, sumberdaya social, sumberdaya fisik, sumberdaya finansial

- Analisis perubahan kualitas livelihood masyarakat sebelum dan setelah menjadi Kampung Pelangi

- Analisis perbedaan kualitas livelihood masyarakat Kampung Pelangi dan Kampung biasa/kampung kontrol (Kampung Pandean).

Penelitian dilakukan di lokasi Kampung Pelangi (RW 3 dan RW 4) Kelurahan Randusari, Kecamatan Semarang Selatan dengan populasi 340 rumah dan di Kampung Pandean dengan populasi 200 rumah yang merupakan permukiman kumuh (Pemerintah Kota Semarang, 2014) yang berlokasi di sebagian Kelurahan Peterongan. Teknik yang digunakan dalam pengambilan sampel dalam penelitian ini adalah probability simple random sampling. Adapun teknik analisis yang digunakan adalah analisis statistik deskriptif dan skoring. Seluruh variabel memiliki bobot yang sama, dengan jawaban terbaik diberi skor 3, jawaban berikutnya diberi skor 2, dan jawaban terburuk diberi skor 1 .

\section{HASIL DAN PEMBAHASAN}

\section{Analisis aset livelihood Kampung Pelangi tahun 2016 dan 2018}

Aset livelihood di Kampung Pelangi meliputi modal sumberdaya manusia, sumberdaya alam, sumberdaya social, sumberdaya fisik, sumberdaya finansial. Analisis aset livelihood di Kampung Pelangi bertujuan untuk mengetahui kualitas livelihood masing-masing aset.

a. Sebagian besar masyarakat Kampung Pelangi berpendidikan SMP- SMA, dengan kondisi kesehatan seluruh anggota keluarga, jarang sakit. Mereka memilih memanfaatkan sarana berobat jalan yang berupa puskesmas/poliklinik, memiliki dan sering menggunakan asuransi kesehatan serta melakukan aktivitas masyarakat pada waktu pagi hingga malam hari.

Tabel 1. Kualitas Modal Manusia Kampung Pelangi 2016 dan 2018

\begin{tabular}{lccrl}
\hline \multirow{2}{*}{ Variabel } & \multicolumn{2}{c}{ Total Nilai Variabel } & \multirow{2}{*}{ Perubahan } & \multirow{2}{*}{ Keterangan } \\
\cline { 2 - 4 } & $\mathbf{2 0 1 6}$ & $\mathbf{2 0 1 8}$ & -18 & Menurun \\
\hline tingkat pendidikan & 156 & 138 & -46 & Menurun \\
kondisi kesehatan & 211 & 165 & -10 & Menurun \\
sarana berobat & 167 & 157 & 65 & Meningkat \\
kepemilikan asuransi kesehatan & 158 & 223 & 12 & Meningkat \\
waktu beraktivitas & 129 & 141 & $\mathbf{3}$ & Meningkat \\
\hline Kualitas Modal Manusia & $\mathbf{8 2 1}$ & $\mathbf{8 2 4}$ &
\end{tabular}

Aset livelihood Kampung Pelangi yang berupa Kualitas modal Manusia mengalami peningkatan setelah implementasi program penataan kawasan sungai (Tabel 1).

b. Sumber air bersih berasal dari PDAM, kondisi air sungai yang tidak berwarna dan berbau, serta kondisi RTH sudah tersedianya taman dengan fasilitas lengkap. 
Tabel 2. Kualitas Modal Alam Kampung Pelangi 2016 dan 2018

\begin{tabular}{|c|c|c|c|c|}
\hline \multirow[t]{2}{*}{ Variabel } & \multicolumn{2}{|c|}{$\begin{array}{c}\text { Total Nilai } \\
\text { Variabel }\end{array}$} & \multirow[t]{2}{*}{ Perubahan } & \multirow[t]{2}{*}{ Keterangan } \\
\hline & 2016 & 2018 & & \\
\hline Sumber air bersih & 201 & 201 & 0 & Sama \\
\hline Kondisi air sungai & 159 & 188 & 29 & Meningkat \\
\hline Kondisi RTH & 82 & 156 & 74 & Meningkat \\
\hline Kualitas Modal Alam & 442 & 545 & 103 & Meningkat \\
\hline
\end{tabular}

Aset livelihood di Kampung Pelangi yang berupa kualitas modal alam mengalami peningkatan setelah implementasi program penataan kawasan sungai.

c. Hubungan antar tetangga cukup baik (interaksi sering/bertemu $>5 \mathrm{x}$ seminggu), mempunyai bentuk lembaga lokal dengan frekuensi kegiatan sering ( $>5 \mathrm{x}$ sebulan), akses informasi mudah dengan informasi lengkap, serta tidak pernah terjadi tindak kriminalitas.

Tabel 3. Kualitas Modal Sosial Kampung Pelangi 2016 dan 2018

\begin{tabular}{lccrl}
\hline \multirow{2}{*}{ Variabel } & \multicolumn{2}{c}{ Total Nilai Variabel } & \multirow{2}{*}{ Perubahan } & \multirow{2}{*}{ Keterangan } \\
\cline { 2 - 3 } & $\mathbf{2 0 1 6}$ & $\mathbf{2 0 1 8}$ & & \\
\hline Hubungan antar tetangga & 210 & 209 & -1 & Menurun \\
Bentuk lembaga lokal yang ada & 167 & 168 & 1 & Meningkat \\
Kemudahan akses informasi & 240 & 240 & 0 & Sama \\
Kemanan & 196 & 221 & 25 & Meningkat \\
\hline Kualitas Modal Sosial & $\mathbf{8 1 3}$ & $\mathbf{8 3 8}$ & $\mathbf{2 5}$ & Meningkat \\
\hline
\end{tabular}

Aset livelihood di Kampung Pelangi yang berupa kualitas modal sosial mengalami peningkatan setelah implementasi program penataan kawasan sungai.

d. Kepemilikan rumah milik sendiri, status tanah tanah hak milik, jenis rumah rumah permanen, tersedia fasilitas MCK pribadi, melakukan pembuangan sampah di TPS. Kondisi air bersih tersedia dengan kualitas baik dan lancar, listrik tersedia merata dan jarang terjadi pemadaman. Ketersediaan sarana telekomunikasi berupa sinyal BTS lancar. Kondisi jalan baik berupa jalan aspal dan tersedia fasilitas transportasi dengan banyak pilihan moda ( $>2$ moda). Ketersediaan fasilitas pendidikan yang merata, lengkap, kondisi baik, serta tersedianya fasilitas kesehatan yang merata dan mudah dijangkau.

Tabel 4. Kualitas Modal Fisik Kampung Pelangi 2016 dan 2018

\begin{tabular}{lrrrrl}
\hline \multirow{2}{*}{ Variabel } & \multicolumn{2}{c}{ Total Nilai } & \multirow{2}{*}{$\begin{array}{c}\text { Perubaha } \\
\text { Variabel }\end{array}$} & Keterangan \\
\cline { 2 - 3 } & $\mathbf{2 0 1 6}$ & $\mathbf{2 0 1 8}$ & $\mathbf{n n n n}$ & \\
\hline Kepemilikan rumah & 165 & 166 & 1 & Meningkat \\
Status tanah & 177 & 181 & 4 & Meningkat \\
Jenis rumah & 221 & 228 & 7 & Meningkat \\
Ketersediaan fasilitas MCK & 238 & 238 & 0 & Sama \\
Perilaku membuang sampah rumah & 225 & 238 & 13 & Meningkat \\
tangga & 238 & 238 & & Sama \\
Kondisi air bersih & 220 & 222 & 2 & Meningkat \\
Ketersediaan listrik & 165 & 163 & -2 & Menurun \\
Ketersediaan sarana telekomunikasi & 192 & 206 & 14 & Meningkat \\
Kondisi jalan & 233 & 238 & 5 & Meningkat \\
Ketersediaan fasilitas transportasi & 238 & 238 & 0 & Sama \\
Ketersediaan fasilitas pendidikan & 240 & 240 & 0 & Sama \\
Ketersediaan fasilitas kesehatan & $\mathbf{2 5 5 2}$ & $\mathbf{2 5 9 6}$ & $\mathbf{4 4}$ & Meningkat \\
\hline Kualitas Modal Fisik & & & & \\
\hline
\end{tabular}

Aset livelihood di Kampung Pelangi yang berupa kualitas modal fisik mengalami peningkatan setelah implementasi program penataan kawasan sungai. 
e. Jumlah pendapatan penduduk hanya terbatas sesuai UMR yang bersumber dari 1 (satu) jenis pekerjaan. Meskipun demikian kondisi ini cukup dapat memenuhi kebutuhan dan masih bisa menabung di koperasi/bank. Sebagian besar dari mereka masih memanfaatkan pinjaman untuk modal pemenuhan kebutuhan sehari-hari dengan pilihan cara pengembalian pinjaman jangka waktu lebih dari setahun dengan bunga $<5 \%$.

Tabel 5. Kualitas Modal Finansial Kampung Pelangi 2016 dan 2018

\begin{tabular}{lrrrl}
\hline \multirow{2}{*}{ Variabel } & \multicolumn{2}{c}{ Total Nilai Variabel } & \multirow{2}{*}{ Perubahan } & \multirow{2}{*}{ Keterangan } \\
\cline { 2 - 3 } & $\mathbf{2 0 1 6}$ & $\mathbf{2 0 1 8}$ & 5 & Meningkat \\
\hline Jumlah pendapatan & 151 & 156 & 2 & Meningkat \\
Sumber pendapatan & 101 & 103 & 1 & Meningkat \\
Pemenuhan kebutuhan pokok keluarga & 187 & 188 & 4 & Meningkat \\
Kepemilikan tabungan & 193 & 197 & -42 & Menurun \\
Penggunaan modal pinjaman & 175 & 133 & 0 & Sama \\
Cara pengembalian pinjaman & 236 & 236 & $\mathbf{- 3 0}$ & Menurun \\
\hline Kualitas Modal Finansial & 1043 & 1013 & & \\
\hline
\end{tabular}

Aset livelihood di Kampung Pelangi yang berupa kualitas modal finansial mengalami penurunan setelah implementasi program penataan kawasan sungai.

\section{Analisis Perubahan Kualitas Livelihood Kampung Pelangi}

Terjadi perubahan livelihood di Kampung Pelangi tahun 2016 dan 2018 yang berupa peningkatan kualitas livelihood (modal manusia, alam, sosial, dan fisik), dan penurunan pada modal finansial (Gambar 2). Hal ini sesuai dengan hasil penelitian dari Archer, 2012 mengenai program peningkatan kualitas permukiman kumuh Baan Mangkong, Thailand yang menyatakan bahwa peningkatan modal fisik (status tanah dan infrastruktur) mempengaruhi peningkatan livelihood masyarakat. Kelima modal penghidupan masyarakat Kampung Pelangi memiliki keterkaitan. Keterkaitan ini mengimplikasikan adanya hubungan diantara kelima modal tersebut yang saling mempengaruhi.

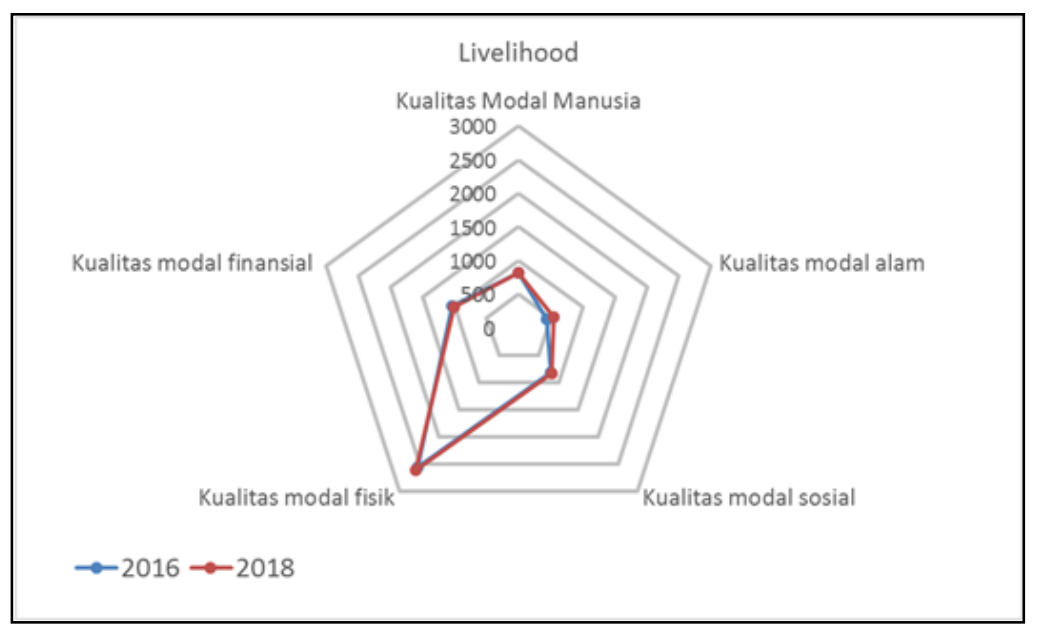

Gambar 2. Perubahan Livelihood Kampung Pelangi tahun 2016 dan 2018

\section{Analisis Perubahan Kualitas Livelihood Kampung Pandean tahun 2016 dan 2018}

Analisis Livelihood Kampung Pandean bertujuan untuk menganalisisi kualitas Livelihood Kampung Pandean (tahun 2016 dan 2018) sebagai kampung kontrol, mencakup kelima modal livelihood (modal manusia, modal alam, modal sosial, modal fisik, dan modal 
finansial). Berdasarkan hasil analisis diketahui bahwa Livelihood Kampung Pandean pada tahun 2016-2018 tidak mengalami perubahan kualitas livelihood. (Tabel 5 dan Gambar 3,)

Tabel 5. Livelihood Kampung Pandean 2016 dan 2018

\begin{tabular}{|c|c|c|c|c|}
\hline No & Modal Livelihood & Variabel & Tahun 2016 & Tahun 2018 \\
\hline \multirow[t]{6}{*}{1} & \multirow[t]{5}{*}{ Modal Manusia } & tingkat pendidikan & 120 & 120 \\
\hline & & kondisi kesehatan & 213 & 213 \\
\hline & & sarana berobat & 140 & 140 \\
\hline & & Kepemilikan asuransi kesehatan & 123 & 123 \\
\hline & & waktu beraktivitas & 138 & 138 \\
\hline & \multicolumn{2}{|c|}{ Kualitas Modal Manusia } & 734 & 734 \\
\hline \multirow[t]{4}{*}{2} & \multirow[t]{3}{*}{ Modal Alam } & Sumber air bersih & 200 & 200 \\
\hline & & Kondisi air sungai & 145 & 145 \\
\hline & & Kondisi RTH & 95 & 95 \\
\hline & \multicolumn{2}{|c|}{ Kualitas Modal Alam } & 440 & 440 \\
\hline \multirow[t]{5}{*}{3} & \multirow[t]{4}{*}{ Modal Sosial } & Hubungan antar tetangga & 234 & 234 \\
\hline & & Bentuk Lembaga Lokal & 149 & 149 \\
\hline & & Kemudahan Akses Informasi & 237 & 237 \\
\hline & & Tingkat Kriminalitas & 228 & 228 \\
\hline & \multicolumn{2}{|c|}{ Kualitas Modal Sosial } & 848 & 848 \\
\hline \multirow[t]{13}{*}{4} & \multirow[t]{12}{*}{ Modal Fisik } & Kepemilikan Rumah & 179 & 179 \\
\hline & & Status Tanah & 106 & 106 \\
\hline & & Jenis Rumah & 159 & 159 \\
\hline & & Ketersediaan Fasilitas MCK & 206 & 206 \\
\hline & & Tempat Pembuangan Sampah & 224 & 224 \\
\hline & & Sumber Air Bersih & 237 & 237 \\
\hline & & Ketersediaan Listrik & 212 & 212 \\
\hline & & Sarana Telekomunikasi & 160 & 160 \\
\hline & & Kondisi Jalan & 213 & 213 \\
\hline & & Fasilitas Transportasi & 162 & 162 \\
\hline & & Fasilitas Pendidikan & 162 & 162 \\
\hline & & Fasilitas Kesehatan & 232 & 232 \\
\hline & \multicolumn{2}{|c|}{ Kualitas Modal Fisik } & 2252 & 2252 \\
\hline \multirow[t]{7}{*}{5} & \multirow[t]{6}{*}{ Modal Finansial } & Jumlah Pendapatan & 102 & 102 \\
\hline & & Sumber Pendapatan & 110 & 110 \\
\hline & & Pemenuhan Kebutuhan Pokok & 148 & 148 \\
\hline & & Kepemilikan tabungan & 146 & 146 \\
\hline & & Penggunaan Modal Pinjaman & 161 & 161 \\
\hline & & Cara Pengembalian Pinjaman & 229 & 229 \\
\hline & \multicolumn{2}{|c|}{ Kualitas Modal Finansial } & 896 & 896 \\
\hline
\end{tabular}

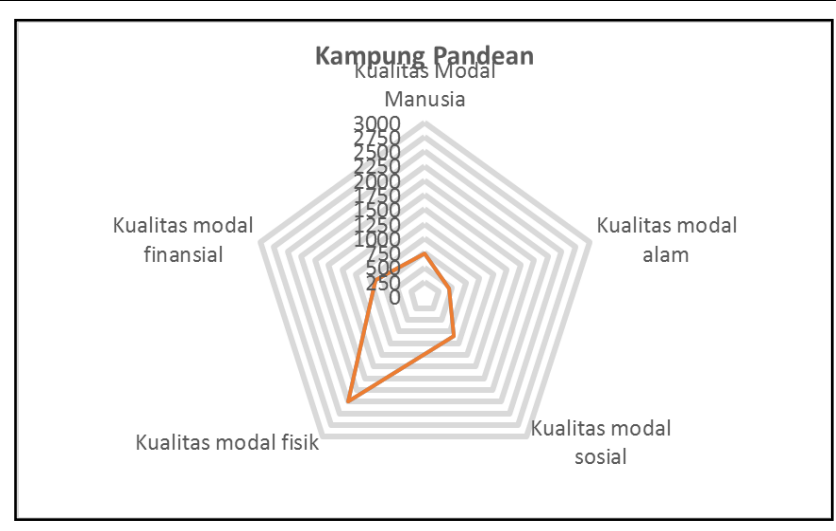

Gambar 3. Kualitas LivelihoodKampung Pandean tahun 2016 dan 2018 


\section{Analisis Perbedaan Kualitas Livelihood Kampung Pelangi dan Kampung Pandean}

Perbedaan kualitas livelihood Kampung Pelangi dan Kampung Pandean dapat dijelaskan berdasarkan kondisi perubahan livelihood kedua kampong tersebut pada tahun 2016-2018. Berdasarkan perbandingan kondisi livelihood Kampung Pelangi dan Kampung Pandean pada tahun yang sama menunjukkan bahwa terjadi perubahan livelihood di Kampung Pelangi sebagai kampung yang mendapat program perbaikan kawasan pinggir sungai sementara di Kampung Pandean sebagai kampung yang tidak mendapat program serupa tidak terjadi perubahan (Tabel 6). Total perhitungan skor livelihood Kampung Pelangi dan Kampung Pandean menunjukkan adanya perubahan (Gambar 3).

Penelitian serupa juga pernah dilakukan di Negara Cina dan Turki. Program yang diterapkan di kedua negara tersebut gagal meningkatkan livelihood masyarakatnya. Program perbaikan kampong di Art Village, Beijing, Cina berhasil memperbaiki kualitas kampung mereka namun justru membuat masyarakat asli terusir sehingga livelihood mereka menurun (Liu, et al, 2013). Sementara program relokasi masyarakat Gecekondu, Turki tentang penanganan masalah permukiman kumuh mengalami kegagalan karena masyarakat kembali menginformalisasi diri mereka sehingga livelihood masyarakatnya kembali seperti semula (Erman, 2016).

Tabel 6. Total Skor Livelihood Kampung Pelangi dan Kampung Pandean tahun 2016 dan 2018

\begin{tabular}{clrrrrr}
\hline \multirow{2}{*}{ No } & \multirow{2}{*}{ Modal } & \multicolumn{2}{c}{ Kampung Pelangi } & \multicolumn{2}{c}{ Kampung Pandean } \\
\cline { 3 - 6 } & & \multicolumn{2}{c}{ Tahun 2016 } & Tahun 2018 & Tahun 2016 & Tahun 2018 \\
\hline 1 & Modal Manusia & 821 & 824 & 734 & 734 \\
2 & Modal Alam & 442 & 545 & 734 & 734 \\
3 & Modal Sosial & 813 & 838 & 440 & 440 \\
4 & Modal Fisik & 2552 & 2596 & 440 & 440 \\
5 & Modal Finansial & 1043 & 1013 & 848 & 848 \\
\hline \multicolumn{2}{l}{ Total Skor } & $\mathbf{5 6 7 1}$ & $\mathbf{5 8 1 6}$ & $\mathbf{3 1 9 6}$ & $\mathbf{3 1 9 6}$ \\
\hline
\end{tabular}

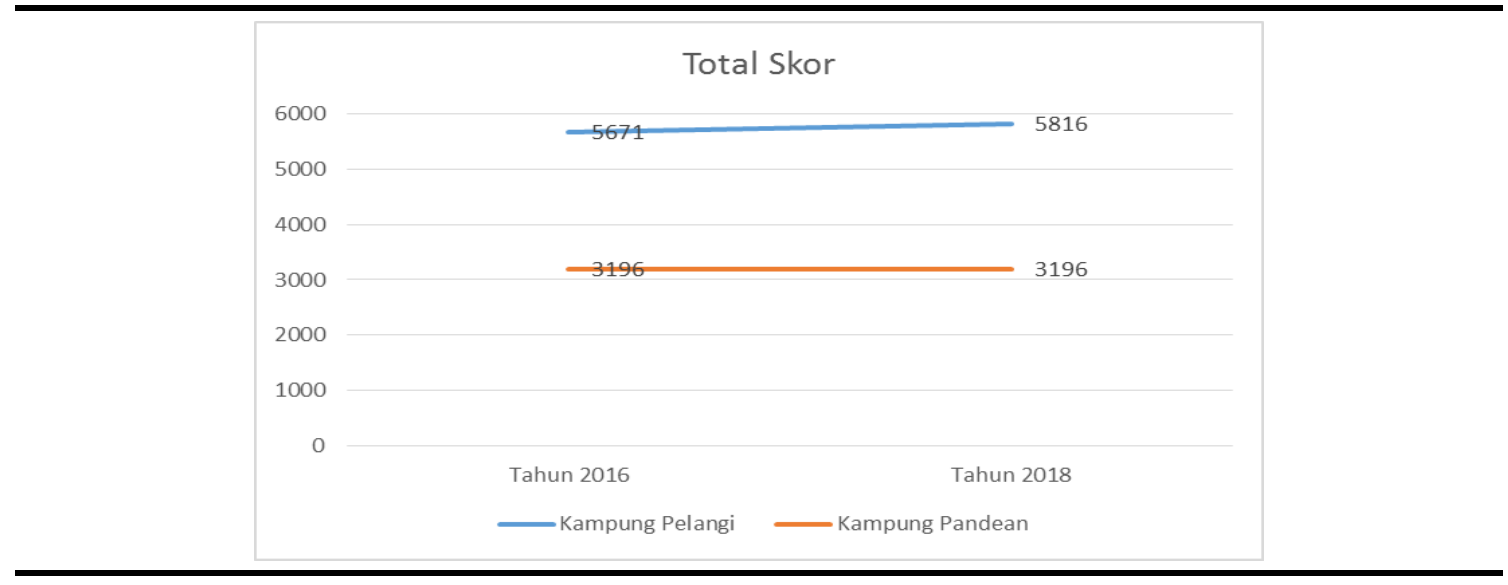

Gambar 4. Total Skor Livelihood Kampung Pandean dan Kampung Pelangi tahun 2016 dan 2018

\section{KESIMPULAN}

Berdasarkan hasil penelitian dapat disimpulkan bahwa Kampung Pelangi mengalami perubahan livelihood penduduknya karena mendapat program dari Pemerintah Kota Semarang tentang penataan kawasan permukiman di pinggir sungai, sedangkan Kampung Pandean yang tidak mendapat program dari Pemerintah Kota Semarang tentang penataan kawasan permukiman kondisi livelihood penduduknya tidak mengalami perubahan. 
Pewarnaan kampung Pelangi terbukti tidak memberikan pengaruh terhadap peningkatan livelihood masyarakat Kampung Pelangi sehingga menjadi lebih baik, karena perubahan yang terjadi disebabkan oleh perbaikan fisik.

Perubahan yang terjadi disebabkan adanya peningkatan kualitas livelihood di Kampung Pelangi meliputi Kualitas Modal Manusia, Kualitas modal alam, Kualitas modal sosial, dan Kualitas modal fisik. Hal ini sesuai dengan hasil penelitian dari Archer, 2012. Penelitian serupa yang dilakukan di Surabaya menunjukkan peningkatan livelihood masyarakat disebabkan oleh aspek fisik, sosial, dan ekonomi yang berperan secara seimbang (Dianingrum et al., 2017).

\section{UCAPAN TERIMA KASIH}

Terima kasih. kepada seluruh staf Kantor Kecamatan, BPS, Bappeda (Badan Perencanaan Pembangunan Daerah) sebagai lembaga penyedia data dan Sekolah Arsitektur, Perencanaan, dan Pengembangan Kebijakan Institut Teknologi Bandung yang telah memberikan kesempatan untuk melakukan penelitian. Ucapan terima kasih juga saya sampaikan kepada semua penulis artikel/jurnal/ buku yang digunakan sebagai referensi.

\section{DAFTAR PUSTAKA}

Archer, D. (2012). Baan Mankong participatory slum upgrading in Bangkok, Thailand: Community perceptions of outcomes and security of tenure. Habitat International, 36(1), 178-184. https://doi.org/10.1016/j.habitatint.2011.08.006

Ashley, C., \& Carney, D. (1999). Sustainable livelihoods: Lessons from early experience. Development, 64.

Balchin, P. N. (1979). Housing Improvement and Social Inequality: Case Study of an Inner City. Saxon House.

Balee, G. J., \& Jruek, K. (2006). Kajian penghidupan berkelanjutan, (497).

Calderon, C. (2012). Social Urbanism: Participatory urban upgrading in Medelin, Colombia. Requalifying the Built Environment: Challenges and Responses, 179-198.

Chambers, R., \& Conway, G. R. (1991). Sustainable Rural Livelihoods: Practical Concepts for the 21st Century. Ids Discussion Paper, 296(Brighton: Institute of Development Studies, University of Sussex), 29. https://doi.org/ISBN 0903715589

de Sherbinin, A., VanWey, L. K., McSweeney, K., Aggarwal, R., Barbieri, A., Henry, S., ... Walker, R. (2008). Rural household demographics, livelihoods and the environment. Global Environmental Change, 18(1), 38-53. https://doi.org/10.1016/j.gloenvcha.2007.05.005

Dianingrum, A., Faqih, M., \& Septanti, D. (2017). Development of Kampung Improvement Program in Surabaya, Indonesia. The International Journal of Engineering and Science, 6(7), 41-47. https://doi.org/10.9790/1813-0607014147

Erman, T. (2016). Formalization by the State, Re-Informalization by the People: A Gecekondu Transformation Housing Estate as Site of Multiple Discrepancies. International Journal of Urban and Regional Research, 40(2), 425-440. https://doi.org/10.1111/1468-2427.12349

Fang, Y. P., Fan, J., Shen, M. Y., \& Song, M. Q. (2014). Sensitivity of livelihood strategy to livelihood capital in mountain areas: Empirical analysis based on different settlements in the upper reaches of the Minjiang River, China. Ecological Indicators, 38, 225-235. https://doi.org/10.1016/j.ecolind.2013.11.007

FAO. (2008). Socio-Economic \& Livelihood Analysis in Investment Planning @ .

Farrington, J., Ramasut, T., \& Walker, J. (2002). Sustainable Livelihoods Approaches in Urban Areas: General Lessons, with Illustrations from Indian Cases. London.

Ikatan Ahli Perencanaan Direktorat Jenderal Cipta Karya. (1998). Kamus Tata Ruang. Direktorat Jenderal Cipta Karya, Departemen Pekerjaan Umum bekerjasama dengan Ikatan Ahli Perencanaan Indonesia.

Khalifa, M. A. (2015). Evolution of informal settlements upgrading strategies in Egypt: From negligence to participatory development. Ain Shams Engineering Journal, 6(4), 1151-1159. https://doi.org/10.1016/j.asej.2015.04.008

Liu, X., Han, S. S., \& O’Connor, K. (2013). Art villages in metropolitan Beijing: A study of the location dynamics. Habitat International, 40, 176-183. https://doi.org/10.1016/j.habitatint.2013.04.005 
Liu, Z., \& Liu, L. (2016). Characteristics and driving factors of rural livelihood transition in the east coastal region of China: A case study of suburban Shanghai. Journal of Rural Studies, 43, 145-158. https://doi.org/10.1016/j.jrurstud.2015.12.008

McGee, T. G. (1996). On the utility of dualism: the informal sector and mega - urbanization in developing countries. Regional Development Dialogue, 17(1), 1-15.

Meikle, S., Ramasut, T., \& Walker, J. (2001). Sustainable Urban Livelihoods: Concepts and Implications for Policy Sustainable Urban Livelihoods: Concepts and Implications for Policy Sustainable Urban Livelihoods: Concepts and Implications for Policy. Development, 33(112), 361-375. https://doi.org/10.1108/03068290610660643

Menteri Pekerjaan Umum dan Perumahan Rakyat. (2016). Peraturan Menteri Pekerjaan Umum dan Perumahan Rakyat Nomor 02 Tahun 2016 tentang Kualitas Terhadap Perumahan Kumuh dan Permukiman Kumuh. Kementerian Pekerjaan Umum Dan Perumahan Rakyat,. Kementerian Pekerjaan Umum Dan Perumahan Rakyat, 1-36.

Nas, P. J. M. (Ed.). (1986). The Indonesian City: Studies in Urban Development and Planning. Dordrecht: Dordrecht, Holland ; Cinnaminson, N.J. : Foris Publications.

Patel, K. (2013). A successful slum upgrade in Durban: A case of formal change andinformal continuity. Habitat International, 40, 211-217. https://doi.org/10.1016/j.habitatint.2013.05.005

Pemerintah Kota Semarang. (2014). Lampiran Keputusan Wali Kota Semarang Nomor 050/801/2014 Tentang Penetapan Lokasi lingkungan Perumahan dan Permukiman Kumuh Kota Semarang.

Saragih, S., J. L. dan A. R. (2007). Kerangka Penghidupan Berkelanjutan Sustainable Livelihood Framework.

Turner, J. C. (1968). Housing Priorities, Settlement Patterns, and Urban Development in Modernizing Countries. Journal of the American Planning Association, 34(6), 354-363. https://doi.org/10.1080/01944366808977562

Undang Undang No.1. (2011). Undang Undang Republik Indonesia Nomor 1 Tahun 2011 tentang Perumahan dan Kawasan Permukiman. Republik Indonesia, 136. 